\title{
Kininase I Activity in Human Fluids and Tissues of the
} Urogenital Tract

\begin{tabular}{|l|l|l|}
\hline D. & Dirk & Hendriks $^{\mathrm{a}}$ \\
\hline S. & Simon & Scharpé $^{\mathrm{a}}$ \\
\hline K. & Koenraad & Van Camp $^{\mathrm{b}}$ \\
\hline M. & Marc & van Sande $^{\mathrm{b}}$ \\
\hline
\end{tabular}

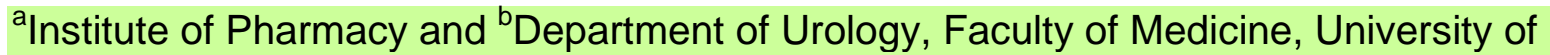
Antwerp, Wilrijk, Belgium

\section{Key Words}

Kininase I

Carboxypeptidase $\mathrm{N}$

Urogenital tract

\section{Abstract}

Kininase I (EC 3.4.17.3) activity has been determined in human fluids and tissues of the urogenital tract. Benzoylglycyl- $L$-arginine and benzoyl-glycyl- $L$-lysine were used as substrates. The cleaved benzoyl-glycine was measured by means of high performance liquid chromatography. Results obtained showed a high enzymatic activity for kidney cortex. Normal prostate, benign prostatic hyperplasia and prostatic adenocarcinoma showed similar enzymic values. The activity of kininase I was higher in normal serum than in the tissues studied.

Dr. Marc van Sande, Faculty of Medicine, Unit of Urology, Building S., Room 4.54, University of Antwerp, B-2610 Wilrijk (Belgium)

Introduction

Kininase I (carboxypeptidase N, arginine carboxypeptidase; EC 3.4.17.3) cleaves carboxyterminal amino acids from various peptides in human plasma: the enzyme removes C-terminal arginine from kinins (bradyki-nin and kallidin) and anaphylatoxins $\mathrm{Q}^{\wedge} \mathrm{a}, \mathrm{C} 4 \mathrm{a}$ and $\mathrm{C5a}$ [Erdös, 1979; Bokish et al., 1970], and it releases lysine from fibrinopeptides [Belew et al., 1984] and from the creatine kinase MM-isoenzyme [Edwards et al., 1984; Perryman et al., 1984]. Very little is known about the origin of the enzyme in the human body, as nearly no studies have been carried out on the enzyme activity in tissues. It was suggested that the enzyme originated from the liver [Erdös et al., 1965], since low enzyme activities were found in sera from patients suffering from cirrhosis of the liver.

Kininase I or carboxypeptidase $\mathrm{N}$ exists in two forms: carboxypeptidase $\mathrm{Nl}$ (CNi) and carboxypeptidase N2 (CN2) [Schweisfurth, 1984], which can be differentiated by their activities towards benzoyl-glycyl-L-arginine and benzoyl-glycyl-L-lysine, respectively.

Here, we report on the kininase I activity in human tissues and fluids from the urogenital tract. Material and Methods

Kidney (cortex and medulla), benign prostatic hyperplasia from untreated patients, normal and adenocarcinomatous prostate (untreated), urinary bladder and testis were obtained by open surgery. Seminal plasma was from healthy donors, prostatic fluid from vasectomized subjects. Serum samples were obtained from blood-bank donors. 
The tissues were placed in liquid nitrogen as soon as possible and brought to the laboratory, where analysis was carried out immediately, or were stored at $-80^{\circ} \mathrm{C}$. The fluids were stored at $25^{\circ} \mathrm{C}$.

The tissues were homogenized in a Teflon-coated Potter-El-vehjem homogenizer, adding one drop of a nonionic surfactant (Nonidet; LKB, Bromma, Sweden) to $200 \mathrm{mg}$ tissue. After centrifugation at 50,000 $\mathrm{g}$ at $4{ }^{\circ} \mathrm{C}$ during $60 \mathrm{~min}$, the supernate was used for the enzymatic determination. Total protein in the superna-tants and the biological fluids was determined according to Dou-mas [1975].

Kininase I activity was determined using benzoyl-glycyl-L-arginine and benzoyl-glycyl-L-lysine as the substrates. We used a recently developed high performance liquid chromatography assisted assay [Hendriks et al., 1985], which is based on the determination of the liberated benzoyl-glycine end-product, in the presence of an internal standard (o-methylbenzoyl-glycine). Each determination was carried out in duplicate.

One unit (U) of kininase I activity is defined as the amount of enzyme required to release $1 \mu \mathrm{mol}$ of benzoyl-glycine per minute at $37^{\circ} \mathrm{C}$ under the assay conditions described.

Kininase I Activity in the Urogenital Tract

95

ENZYME ACTIVITY U/g protein

$\mathrm{v} \backslash \mathrm{i}-$

$-{ }^{\mathrm{a}}$

Î́1 i.

Fig. 1. Distribution of kininase I activities in human tissues and fluids of the urogenital tract.

Hatched bars indicate the enzymatic activity towards benzoyl-glycyl-L-arginine (CNi), open bars towards benzoyl-glycyl-L-lysine (CN2). $\mathrm{BPH}=$ Benign prostatic hyperplasia.

Results

The results obtained, expressed in units per gram protein, are represented in figure 1. Particularly striking are the nearly identical results obtained in normal, adeno-matous and

adenocarcinomatous prostate.

Discussion

References

Belew, M.; Gerdin, B.; Lindeberg, G.; Porath, J.; Wallin, R.: Structure-activity relationships of vasoactive peptides derived from fibrin or fibrinogen degraded by plasmin. Biochim. biophys. Acta 662: 300-307 (1981:

Bokish, V.A.; Muller-Eberhard, H.J.: Anaphylotoxin inactivator of human plasma: its isolation and characterization as a carboxy-peptidase. J. clin. Invest. 49: 2427-2436 (1970).

Doumas, B.T.: Standard for total protein assay. A collaborative study. Clin. Chem. 21: 11591166 (1975).

Edwards, R.J.; Watts, D.C.: Human ‘creatinine kininase conversion factor’ identified as a carboxypeptidase. Biochem. J. 221: 465-470(1984).

Erdös, E.G.: Bradykinin, kallidin and kallikrein; in Erdös, Handbook of experimental pharmacology (Springer, New York 1979).

Erdös, E.G.; Wohler, J.M.; Levine, M.J.; Westerman, M.P.: Carboxypeptidase in blood and other fluids. Values in human blood in normal and pathological conditions. Clin. chim. Acta 11: 3943(1965). 
Hendriks, D.; Scharpé, S.; Sande, M. van: Assay of carboxypeptidase N activity in serum by liquid-chromatographic determination of hippuric acid. Clin. Chem. 31: 1936-1939 (1985). Perryman, M; Knell, D.; Robert, S.S.: Carboxypeptidase-catalyzed hydrolysis of c-terminal lysine: mechanism for in vivo production of multiple forms of creatine kinase in plasma. Clin. Chem. 50:662-664(1984).

Schweisfurth, H.: Carboxypeptidase N. Dt. med. Wschr. 109:1254-1258(1984).

All tissues and fluids studied possess a 'kininase I-like' activity, although inferior to the activities found in serum. This suggests that kininase I or kininase I-like enzymes could play a role outside the serum compartment, but it seems unlikely that the serum enzyme originates from one of the tissues studied. However, there is the possibility that an inactive precursor of the enzyme somewhere in the body, enters the bloodstream and then is transformed to active kininase I. 